\title{
Quantification of flood risk mitigation benefits: a building-scale damage assessment through the RASOR platform
}

\author{
Chiara Arrighi ${ }^{\mathrm{a}, *}$, Lauro Rossi ${ }^{\mathrm{b}}$, Eva Trasforini ${ }^{\mathrm{b}}$, Roberto Rudari ${ }^{\mathrm{b}}$, Luca \\ Ferraris $^{\mathrm{b}, \mathrm{c}}$, Marcello Brugioni $^{\mathrm{d}}$, Serena Franceschini ${ }^{\mathrm{d}}$, Fabio Castelli ${ }^{\mathrm{a}}$ \\ ${ }^{a}$ Department of Civil and Environmental Engineering. University of Florence, Via di S. \\ Marta 3, 50139 Firenze, Italy \\ ${ }^{b}$ CIMA Research Foundation, University Campus, Italy \\ ${ }^{c}$ Università degli Studi di Genova - DIBRIS, Via Magliotto 2, Savona, Italy \\ ${ }^{d}$ Autorità di Bacino del Fiume Arno, Via dei Servi 15, Firenze, Italy
}

\begin{abstract}
Flood risk mitigation usually requires a significant investment of public resources and cost-effectiveness should be ensured. The assessment of the benefits of hydraulic works requires the quantification of (i) flood risk in absence of measures, (ii) risk in presence of mitigation works, (iii) investments to achieve acceptable residual risk. In this work a building-scale is adopted to estimate direct tangible flood losses to several building classes (e.g. residential, industrial, commercial, etc.) and respective contents, exploiting various sources of public open data in a GIS environment. The impact simulations for assigned flood hazard scenarios are computed through the RASOR platform which allows for an extensive characterization of the properties and their vulnerability through libraries of stage-damage curves. Recovery and replacement costs are estimated based on insurance data, market values and socio-economic proxies. The methodology is applied to the case study of Florence (Italy) where a system of retention
\end{abstract}

*Corresponding author: Chiara Arrighi. Email: chiara.arrighi@dicea.unifi.it. Department of Civil and Environmental Engineering. University of Florence, Via di S. Marta 3, 50139 Firenze, Italy. Phone/fax number: +39 0552758856.

Email addresses: chiara.arrighi@dicea.unifi.it (Chiara Arrighi),

lauro.rossi@cimafoundation.org (Lauro Rossi), eva.trasforini@cimafoundation.org (Eva Trasforini), roberto.rudari@cimafoundation.org (Roberto Rudari),

luca.ferraris@cimafoundation.org (Luca Ferraris), m.brugioni@adbarno.it (Marcello Brugioni), s.franceschini@adbarno.it (Serena Franceschini), fabio.castelli@unifi.it (Fabio Castelli) 
basins upstream of the city is under construction to reduce flood risk. Current flood risk in the study area $\left(70 \mathrm{~km}^{2}\right)$ is about 170 Mio euros per year without accounting for people, infrastructures, cultural heritage and vehicles at risk. The monetary investment in the retention basins is paid off in about 5 years. However, the results show that although hydraulic works are cost-effective, a significant residual risk has to be managed and the achievement of the desired level of acceptable risk would require about 1 billion euros of investments.

Keywords: cost-benefit analysis, exposure, recovery cost, retention basin, GIS

\section{Introduction}

1 River floods cause relevant damages to property, infrastructures Arrighi et al. 2017), public goods, economic activities and services especially when affecting urban areas with important exposed values, such as historic cities and

5 productive sites, thus affecting the whole society. Accurate estimation of flood impacts is crucial to quantify the actual risk and evaluate the cost-effectiveness of hydraulic mitigation works (Förster et al., 2005, Gouldby et al., 2008: Shreve and Kelman, 2014), which require significant investments. Flood impacts estimates are also crucial for non-structural mitigation measures, such as emergency 10 management (Molinari et al., 2013). A deep understanding of flood risk and possible mitigation strategies is unavoidable to communicate technical findings to institutions and firmly support political decision making (Murnane et al., 2016)

The European Flood directive (EU Parliament, 2007) defines flood risk as the combination of flood hazard, exposure (of population and assets) and vulnerability. The assessment of these three components encompasses various spatial scales, from the catchment, where the structural risk mitigation strategies are designed, to the target receptor (e.g. a single-building or infrastructure) (Burzel et al., 2015). A robust flood risk management strategy usually com-

20 bines hydraulic infrastructure (e.g. dams, retention basins) (Förster et al. 2005, Gouldby et al., 2008, de Moel et al., 2014), whose aim is the hazard 
reduction, and local prevention/preparedness actions to address the residual risk (e.g. civil protection warnings, self protection etc.) (Silvestro et al. 2016). The reduction of flood hazard due to engineering works causes a left shift of the damage-frequency curve, thus lowering the curve integral, commonly known as Expected Annual Damage (EAD).

The assessment of flood damage usually relies on the application of stagedamage curves linking flood depth with the expected adverse consequences (Scawthorn et al., 2006, Van Ootegem et al., 2015, Aye et al., 2016). Flood consequences in case of tangible damages are expressed in terms of economic costs. Recovery and replacement costs are the cost per unit area to be sustained to reconstruct the previous building (i.e. the maximum possible damage) and the cost per unit area to replace existing contents respectively. Damages are linked to recovery cost through damage curves, thus actual damage is a fraction

35 of the recovery cost if only renovation or repair are needed. Consequently two main pieces of information are needed, flood hazard maps and vulnerability of the target asset. Within the framework of the EU Parliament (2007) directive, hazard maps are produced by the competent River District Authority in charge of elaborating Flood Risk Management Plan (FRMP) and available as open re40 source (Sterlacchini et al., 2016). Vulnerability in urban areas is often assessed at micro-scale (Arrighi et al., 2013, Apel et al., 2009: Dottori et al., 2016, Prahl et al., 2016), e.g. at single-building level in order to capture the variability of built-up area in terms of building characteristics (e.g. number of storeys, cellar, construction material) and use (e.g. residential, commercial etc.). However, 45 such a detail requires high-resolution geographic data and attributes. Moreover, major uncertainties still remain in replacement/recovery cost assessment (Meyer et al. 2013$)$ which on one hand may rely on insurance data (PenningRowsell and Pardoe, 2012, Rojas et al., 2013; Alfieri et al., 2016), on the other on socio-economic proxies (Arrighi et al., 2013, Marin and Modica, 2017).

The Arno river catchment is one of the largest in Italy with an extent of $9116 \mathrm{~km}^{2}$. During the catastrophic flood of 1966 the whole catchment was affected (Panattoni and Wallis, 1979, Caporali et al. 2005$)$ and the city of Flo- 
rence, one of the most important art cities in Italy, suffered of incalculable losses to cultural heritage, buildings, infrastructures and economic activities. Nowadays Florence is still threatened by floods, although some protection measures have been undertaken (e.g. dams, adjustments of dikes and bridges). Flood risk, limited to the urban reach of the Arno river, has been estimated approximately equal to 52 million euros per year (Arrighi et al. 2016a). In the last five decades the Arno catchment has been object of several studies, which identified several retention basins (see Table 1) upstream of the city as the most appropriate flood hazard mitigation strategy. Nevertheless, the flood risk reduction is expected to be marginal also for low recurrence interval events, since a significant urban and industrial development took place in flood prone areas after the 1966 flood.

This work aims at evaluating in monetary terms the relative risk reduction of the planned retention basins upstream of the city of Florence and their costeffectiveness for the whole urban and suburban area around the historic city. Although a life-cycle approach could be more robust for cost assessment of mitigation works, here only construction and maintenance costs are considered. The risk assessment accounts for several exposed objects, namely buildings, household contents, commercial contents and industrial contents, with the highest possible spatial resolution in order to capture the spatial variability of exposed values of the area. The hazard assessment is based on the official flood hazard maps developed for the FRMP (Autorità di Bacino del Fiume Arno, 2016b). Vulnerability is evaluated at the single-building scale combining several sources of open socio-economic data in a GIS environment in order to enrich the attributes of the exposed asset, thus obtaining a more reliable description of the building use. Replacement costs account for market values, census data and insurance data to properly describe urban spatial variability. Damage calculations are carried out within the RASOR platform (Silvestro et al., 2016, Rudari 80 and RASOR TEAM, 2015; Koudogbo et al. 2014). It is widely acknowledged that a flood damage estimation without validation against local historical loss data may sound weak (Ballio et al., 2015). Unfortunately for the presented case study such data are not available. However, the damage curves libraries of 
the RASOR platform performed very well in another italian case study when

compared to citizen claims and municipal authorities surveys, thus the model is considered reliable at least for comparing several scenarios in the study area (Silvestro et al., 2016; Trasforini et al., 2015). In order to answer the common stakeholders' question "How much should I invest to achieve the desired residual risk?" a section has been dedicated to the description of analytical methods to estimate the benefits of flood risk mitigation and the investment required to obtain an assigned risk reduction.

This article is organized as follows. Section 2 introduces the study area and the risk mitigation measures that have been considered. The methodology to characterize the exposed assets, the costs estimation and risk-benefit analysis is 95 outlined in section 3. The outcomes of the flood risk assessment are presented in section 4 . The article ends with the concluding section, elaborating on the effectiveness of measures and future developments. 


\section{Case study}
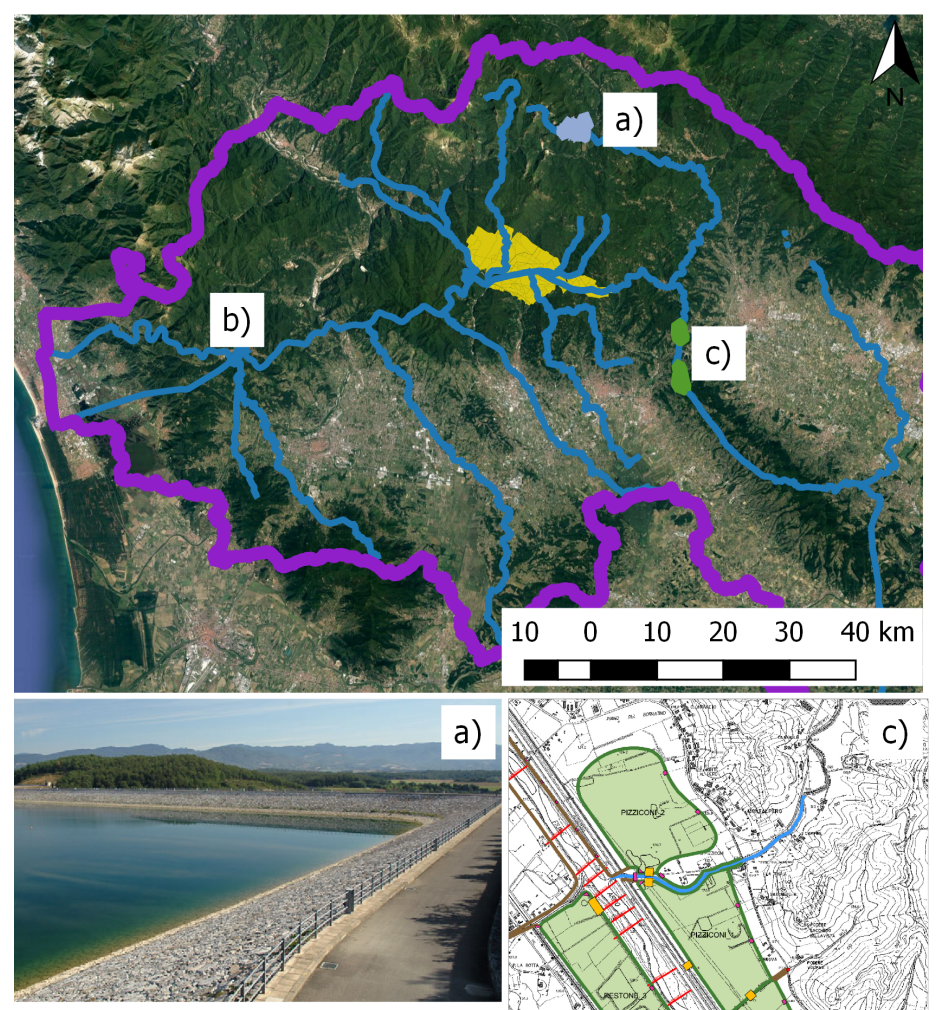

)
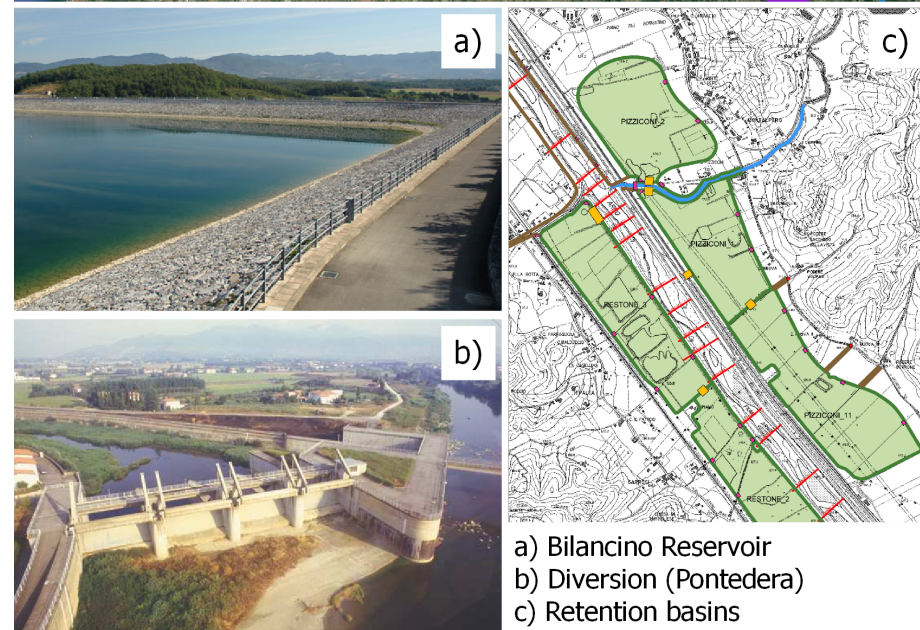

b)

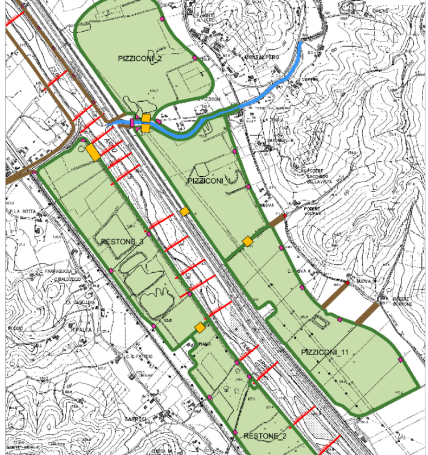

a) Bilancino Reservoir

b) Diversion (Pontedera)

c) Retention basins

Figure 1: Map of the Arno river catchment showing the location of flood mitigation works: (a) Bilancino reservoir (image source www.adbarno.it), (b) river diversion (image source www.adbarno.it), (c) new system of retention basins (image source Tuscany Region) and the metropolitan area of Florence (yellow area).

The Arno river catchment represented with purple line in the map of Fig. ${ }_{100}$ 1. is located in central Italy and covers an area of $9116 \mathrm{~km}^{2}$ It has 2.2 million inhabitants mostly concentrated along the main stream and its tributaries. 
Most of the floodplains along Arno river are protected by dikes. Currently, two main hydraulic works contribute to mitigate flood hazard in the catchment: the Bilancino reservoir and the river diversion in Pontedera (Pisa) Fig. 1.

The Bilancino reservoir (panel a, Fig. 1), operational since 1995, is located upstream of the city of Florence in the river Sieve, one of the main right tributaries of the Arno river. Its maximum storage capacity is 84 million $m^{3}$ used for energy production, flood lamination, drinking water supply and recreational purposes.

The river diversion in Pontedera (panel b, Fig. 1), concluded in 1987 is located in the lower Arno stream between Florence and Pisa. Its primary purpose is the protection of the city of Pisa from the floods. The river diversion consist of a $28 \mathrm{~km}$ channel capable of diverting a maximum discharge of approximately $1000 \mathrm{~m}^{3} / \mathrm{s}$ from the Arno river in order to reduce the peak flow discharge in the city of Pisa. During one of the most severe floods in 1992 the channel diverted $900 \mathrm{~m}^{3} / \mathrm{s}$. Since its construction, the diversion effectively contributed to hazard mitigation 14 times.

The new system of retention basins currently under construction (an example in panel c of Fig. 1) is located upstream of Florence in the river reach between the municipalities of Figline Valdarno and Rignano sull'arno. The projects cost is about 70 million euros and includes four retention basins (Table 1), which are designed to store $22 \mathrm{Mm}^{3}$. The alteration of mitigation works over time has not been accounted for. Mitigation effectiveness may vary according to operational protocols of the hydraulic works, currently under optimization.

Table 1: Characteristics of the system of retention basins upstream of Florence. (Designed recurrence interval for activation: 30 years.)

\begin{tabular}{llll}
\hline Retention basin & Area $\left(\mathrm{km}^{2}\right)$ & Stored volume $\left(\mathrm{Mm}^{3}\right)$ & Cost (Mio Euro) \\
\hline Restone & 1.09 & 6.03 & 15.9 \\
Pizziconi & 1.21 & 2.47 & 8.0 \\
Leccio & 1.37 & 6.6 & 25.0 \\
Prulli & 1.34 & 6.7 & 25.24 \\
\hline
\end{tabular}


A further measure, currently under study is the increase of the storage capacity of the Levane dam, located upstream of the system of retention basins, with an estimated cost of 25 million euros.

These engineering works have been designed to maximize the stored volume in order to reduce the flood peak discharge in the Florence reach of the Arno river, but so far a quantitative assessment in terms of risk reduction has not been undertaken. The purpose of this study is to quantify the risk reduction and residual risk after the construction of the system of retention basins. The area under study is the city of Florence and its downstream suburban areas which comprise 10 municipalities. In a previous study the direct flood damages of an event of magnitude similar to the 1966 one for the sole urban area have been estimated approximately equal to 4 billion euros (Arrighi et al. 2016a). Of this total amount, 2 billion euros were the estimated losses to buildings, 1.28 billion euros the damages to household contents and the remaining were damages to commercial contents. In that study the census section scale was adopted to estimate flood losses for assigned recurrence scenarios in absence of the new system of retention areas, which at that time were under preliminary design. The census section scale, usually coinciding with a building block in densely populated areas (e.g. historic district) was considered the most suitable scale of analysis for the availability of open socio-economic data and for the possibility 145 of upscaling flood representative parameters (Arrighi et al. 2013). The present study strongly increases the level of detail to the single-building level. Moreover, the census section scale cannot be adopted to the new extension of the study area $\left(117 \mathrm{~km}^{2}\right)$ since the suburban industrial districts (scarcely inhabited) are discretized with large census sections of the order of 0.3 to $5 \mathrm{~km}^{2}$ of area which do not provide an adequate resolution of the information to assign the actual flood depth value to each exposed building. 


\section{Materials and method}

\subsection{Scales of analysis for hazard assessment}

In order to assess the risk reduction due to the planned system of retention basins upstream of the city of Florence the outputs of several scales of analysis are needed (Fig. 2). The hydrologic and climatic characterization of the watershed (left block of Fig. 2 ) are undertaken at catchment scale in order to produce design rainfall and associated statistical flood scenarios Campo et al. 2006).

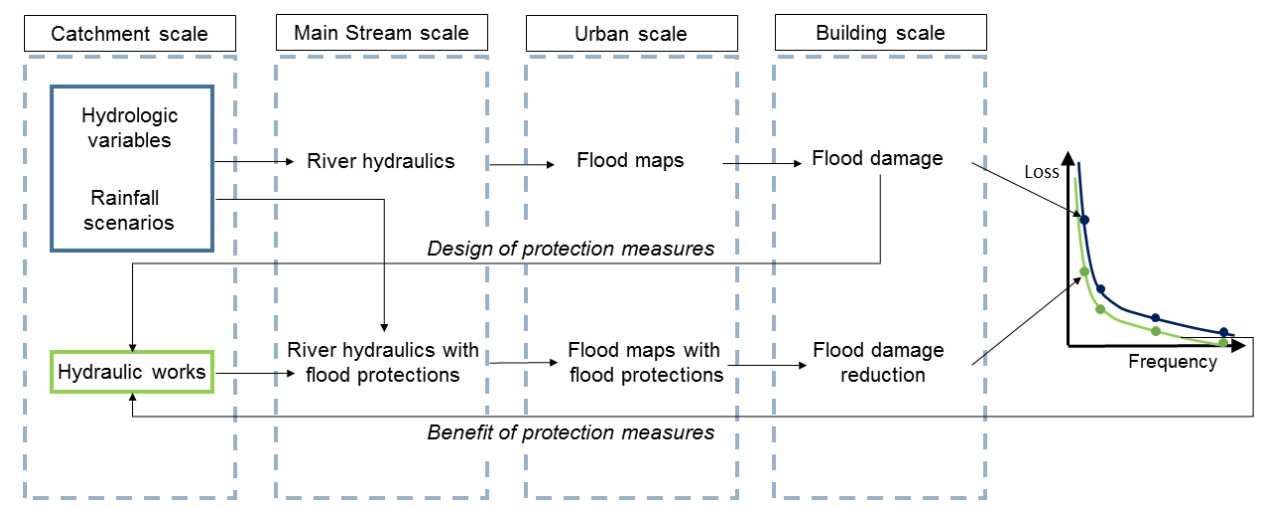

Figure 2: Graphical scheme of the spatial scales involved in flood risk assessment and benefit analysis of hydraulic works.

River hydraulics is performed through a standard solver of the 1D general equation of unsteady flow to obtain water profile along the river. The 1D river model (second block of Fig. 2) uses as boundary conditions the inflow design hydrographs obtained by the catchment scale analysis and quantifies the position and discharge of outflow areas from which the inundation starts. For the considered metropolitan area (third block of Fig. 2) where the outflow from the river banks is present, the inundation volumes are transformed into water depths modeling the floodplain as a system of connected storage areas governed by mass conservation law, stage storage relationships and weir laws accounting 
for backwater effects for the connection. Being the hydraulic model parsimomain use of the building (e.g. industrial, residential, commercial etc.). However, dual use buildings, where a commercial activity is placed at the ground 
floor and the residences are located in the upper floors, are the most common in the study area, particularly in the historic district. Dual use buildings are not captured by the 1:2000 building cartography, thus another geographic feature is exploited to refine the exposure classification. The municipalities (http://opendata.comune.fi.it/) distribute a list of commercial activities and their coordinates as point shapefile as shown in panel $a$ of Fig. 3, where the green dots localize the direct retail activities.

The application of a three meters buffer to the buildings shapefile allows for the count of commercial activities falling inside the polygon through the Point - in - Polygon vector tool. The size of the buffer has been selected in order to avoid overlaps in the historic district with high buildings density. Residential buildings (according to the regional data source) intercepting commercial activities are classified as dual use buildings, i.e. commercial/residential. Figure 3 compares the original building use in a portion of the historic Florence district with the new building use obtained by the GIS operations. Panel $a$ shows the building use as retrieved by the cartography portal, i.e. before the characterization, where the original buildings are represented as residential (light blue polygons). Panel $b$ shows the building use obtained by merging the two sources of geographic information, dual use buildings are depicted with a salmon pink color. Thus 14 exposed categories are classified for the risk analysis instead of the original 13. They are residential, commercial, commercial/residential, 220 hospital, school, industrial, place of worship, offices, sport, parking, transport, agriculture, theaters and leisure activities, campings and temporary lodging. 


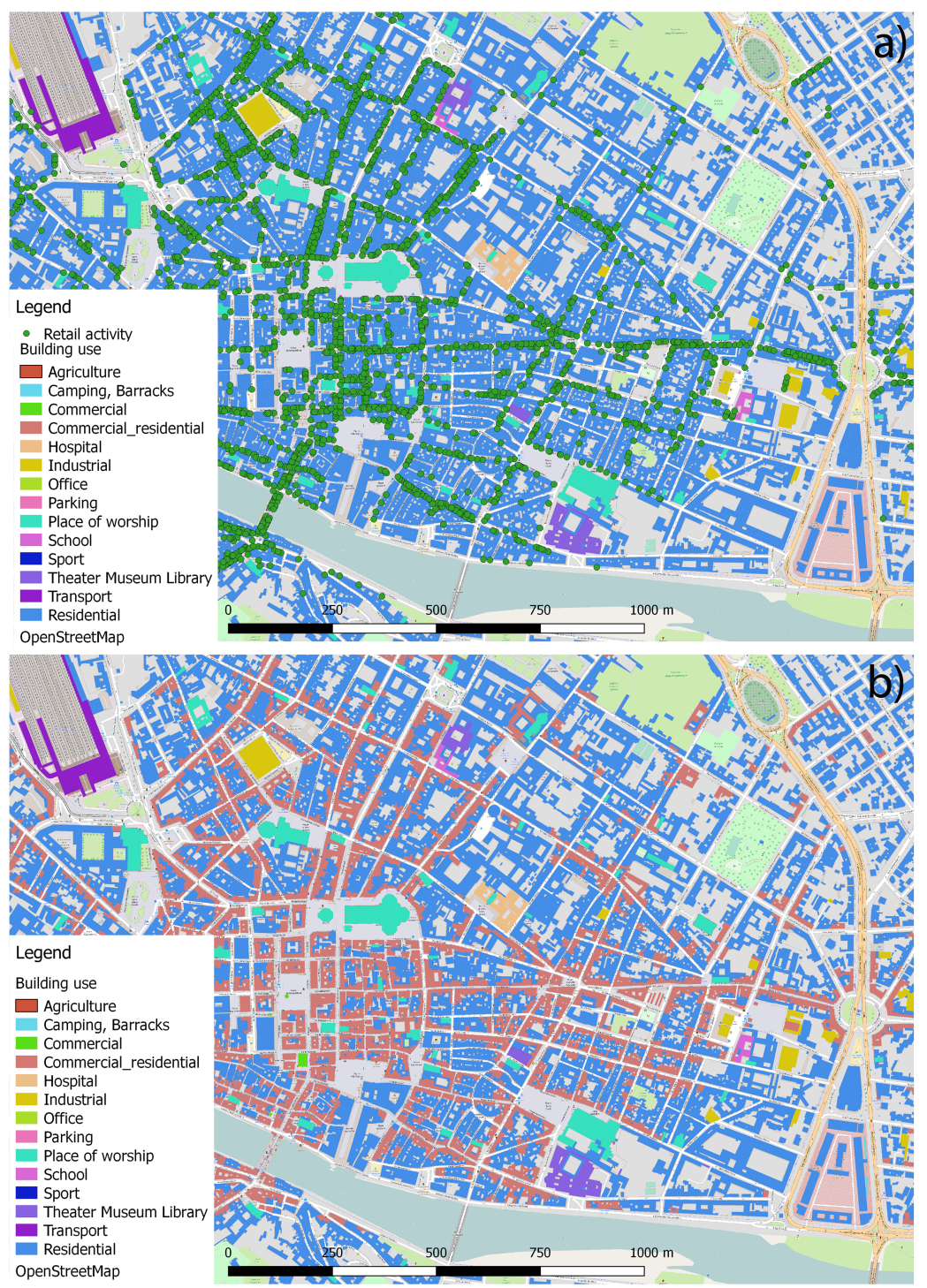

Figure 3: Characterization of single-building use merging the point information about retail activities and main building use (panel a) and the resulting dual use classification commercialresidential (panel b).

Proxies of economic values can be used to estimate the replacement and recovery costs (Arrighi et al., 2013; Marin and Modica, 2017) for structures and contents. The sensitivity analysis carried out in a previous work Arrighi et al. 
costs were assessed, is the most sensitive parameter (elasticity $=0.9$ ). This bears that if recovery cost changes of $1 \%$ the total risk changes of $0.9 \%$. Such a sensitivity is intrinsic of most of damage models since an estimated value (exposure/replacement cost) is multiplied by a relative loss given by damage curves. data, the authors based their the working assumptions on the official insurance data and on the opinion of experts and public stakeholders (co-authors of the manuscript)

In this application, starting from insurance data made available at regional scale by ANIA (Associazione Nazionale fra le Imprese Assicuratrici, 2011) a series of corrective parameters and working assumptions have been defined to adjust regional average values to spatial exposure differences inside the study area. Corrective parameters and economic proxies have been analyzed and assumed based on expert judgment and cooperative debate with stakeholders. The lack of and adopting a what-if approach to synthetically exemplify damage mechanisms and estimate recovery/replacement costs. Where more reliable local data are available, users and practitioners are encouraged to use them for flood risk estimates. As an example of experts' approach, in the historical districts, where buildings, the highest recovery cost in the range has been adopted ANIA is a consortium of insurance companies in Italy, which collected citizen claims after several natural disaster, e.g. earthquakes and floods, in the last decades and estimated potential flood losses aggregated by region and building type. For the recovery costs of industrial structures, the corrective parameters $P$ are evaluated using as proxies the market values made available by GIS portal (GEOPOI) of the National Agency for Fiscal Administration (Agenzia delle Entrate, 2017), which collects and distributes sub-municipal scale data about selling and renting values for several categories. A more extensive use of market values has been 
activities, e.g. manufacturing and commerce. Table 2 summarizes the recovery cost of structures used for the damage estimation. The first column indicates the damage category, the second states the source and value of the base cost, the third states the corrective parameter where defined, the fourth the recovery 2011) for structures and the contents to structure ratio (CSVR) for residential use (USACE, 2006). Several other studies also suggest that residential content is roughly half of the value of the building structure (Huizinga and Szewczyk 2017). Lower values and high values in the range are assigned to suburban 285 
Table 2: Recovery costs for structures

\begin{tabular}{|c|c|c|c|c|}
\hline Building use & $\begin{array}{l}\text { Base value } \\
\text { Euro } / m^{2}\end{array}$ & $\mathrm{P}$ & $\begin{array}{l}\text { Recovery cost } \\
\text { Euro } / m^{2}\end{array}$ & Description \\
\hline Residential & $\begin{array}{l}1055-1630 \\
(\text { ANIA }, 2011)\end{array}$ & 1 & $1055-1630$ & $\begin{array}{l}\text { Regional value taken as is } \\
\text { with maximum assigned to } \\
\text { historic districts and mini- } \\
\text { mum to suburbs }\end{array}$ \\
\hline $\begin{array}{l}\text { Commercial- } \\
\text { residential }\end{array}$ & $\begin{array}{l}1055-1630 \\
(\text { ANIA }, 2011)\end{array}$ & 1 & $1055-1630$ & Regional value taken as is \\
\hline Commercial & $\begin{array}{l}1055-1630 \\
(\text { ANIA }, 2011)\end{array}$ & 1 & $1055-1630$ & $\begin{array}{l}\text { Assimilated to residential } \\
\text { buildings }\end{array}$ \\
\hline Industrial & $\begin{array}{l}1055-1630 \\
(\text { ANIA }, 2011)\end{array}$ & 0.8 & $844-1304$ & $\begin{array}{l}\text { Ratio between residential } \\
\text { and productive market val- } \\
\text { ues (GEOPOI,2017) }\end{array}$ \\
\hline Sport & $\begin{array}{l}1055 \\
(\text { ANIA }, 2011)\end{array}$ & 1 & 1055 & $\begin{array}{l}\text { Minimum of the recovery } \\
\text { cost range for structures }\end{array}$ \\
\hline Hospital & $\begin{array}{l}1055-1630 \\
(\text { ANIA }, 2011)\end{array}$ & 1.2 & $1266-1956$ & Based on expert judgement \\
\hline School & $\begin{array}{l}1055-1630 \\
(\text { ANIA,2011) }\end{array}$ & 1 & $1055-1630$ & $\begin{array}{l}\text { Assimilated to residential } \\
\text { buildings }\end{array}$ \\
\hline $\begin{array}{l}\text { Place of wor- } \\
\text { ship }\end{array}$ & $\begin{array}{l}1055-1630 \\
(\text { ANIA,2011) }\end{array}$ & 1 & 1055 & $\begin{array}{l}\text { Assimilated to low-quality } \\
\text { residential buildings }\end{array}$ \\
\hline Offices & $\begin{array}{l}1055-1630 \\
(\text { ANIA,2011) }\end{array}$ & 1 & $1055-1630$ & $\begin{array}{l}\text { Assimilated to residential } \\
\text { buildings }\end{array}$ \\
\hline Transport & $\begin{array}{l}1055-1630 \\
(\text { ANIA,2011) }\end{array}$ & 1 & $1055-1630$ & $\begin{array}{l}\text { Assimilated to residential } \\
\text { buildings }\end{array}$ \\
\hline Agriculture & $\begin{array}{l}1055 \\
(\text { ANIA,2011) }\end{array}$ & 0.3 & 352 & Based on expert judgement \\
\hline Recreational & $\begin{array}{l}1055-1630 \\
(\text { ANIA,2011) }\end{array}$ & 1 & 1055 & $\begin{array}{l}\text { Minimum of the recovery } \\
\text { cost range for structures }\end{array}$ \\
\hline Parking & $\begin{array}{l}1055 \\
(\text { ANIA,2011) }\end{array}$ & 0.2 & 211 & $\begin{array}{l}\text { Based on regional prices for } \\
\text { road infrastructure main- } \\
\text { tenance (Regione Toscana, } \\
2016 \text { ) }\end{array}$ \\
\hline $\begin{array}{l}\text { Temporary } \\
\text { lodging }\end{array}$ & $\begin{array}{l}1055 \\
(\text { ANIA }, 2011)\end{array}$ & 0.3 & 316 & $\begin{array}{l}\text { Based on regional prices for } \\
\text { temporary wooden lodging } \\
\text { (Regione Toscana, 2016) }\end{array}$ \\
\hline
\end{tabular}


Table 3: Replacement costs for contents

\begin{tabular}{|c|c|c|c|c|}
\hline Building use & $\begin{array}{l}\text { Base value } \\
\text { Euro } / m^{2}\end{array}$ & $\mathrm{P}$ & $\begin{array}{l}\text { Recovery cost } \\
\text { Euro } / m^{2}\end{array}$ & Description \\
\hline Residential & $\begin{array}{l}1055-1630 \\
(\text { ANIA,2011) }\end{array}$ & 0.5 & $528-815$ & $\begin{array}{l}\text { Contents to structure ratio } \\
\text { (USACE, 2006) }\end{array}$ \\
\hline $\begin{array}{l}\text { Commercial- } \\
\text { residential }\end{array}$ & $\begin{array}{l}671 \quad(\mathrm{Av}- \\
\text { erage } \\
\text { residential } \\
\text { content })\end{array}$ & $\begin{array}{l}1 \\
1.45 \\
2\end{array}$ & $\begin{array}{l}671 \text { low dens. } \\
972 \text { medium } \\
1342 \text { high }\end{array}$ & $\begin{array}{l}\text { Based on employees den- } \\
\text { sity (ISTAT, 2012) and } \\
\text { renting ratio comm/resid. } \\
\text { (GEOPOI, 2017) }\end{array}$ \\
\hline Commercial & $\begin{array}{l}671 \quad(\mathrm{Av}- \\
\text { erage } \\
\text { residential } \\
\text { content) }\end{array}$ & $\begin{array}{l}1 \\
1.45 \\
2\end{array}$ & $\begin{array}{l}671 \text { low dens. } \\
972 \text { medium } \\
1342 \text { high }\end{array}$ & $\begin{array}{l}\text { Based on employees den- } \\
\text { sity (ISTAT, 2012) and } \\
\text { renting ratio comm/resid. } \\
\text { (GEOPOI, 2017) }\end{array}$ \\
\hline Industrial & $\begin{array}{l}671 \quad(\mathrm{Av}- \\
\text { erage } \\
\text { residential } \\
\text { content })\end{array}$ & $\begin{array}{l}1.28 \\
1.54\end{array}$ & $\begin{array}{l}860 \text { low dens. } \\
1032 \text { high }\end{array}$ & $\begin{array}{l}\text { Based on employees den- } \\
\text { sity (ISTAT, 2012) and } \\
\text { ratio between industrial } \\
\text { and residential renting val- } \\
\text { ues in suburban districts } \\
\text { (GEOPOI,2017) }\end{array}$ \\
\hline Sport & $\begin{array}{l}521 \quad(\min . \\
\text { resid.) }\end{array}$ & 0.29 & 150 & $\begin{array}{l}\text { Based on regional prices for } \\
\text { sports infrastructure fur- } \\
\text { niture (Regione Toscana, } \\
2016 \text { ) }\end{array}$ \\
\hline Hospital & $\begin{array}{l}521 \quad(\min . \\
\text { resid.) }\end{array}$ & 1.15 & 600 & Based on expert judgement \\
\hline School & $\begin{array}{l}521 \quad(\min . \\
\text { resid.) }\end{array}$ & 0.29 & 150 & Based on expert judgement \\
\hline $\begin{array}{l}\text { Place of wor- } \\
\text { ship }\end{array}$ & $\begin{array}{l}521 \quad(\min . \\
\text { resid.) }\end{array}$ & 0.19 & 100 & Based on expert judgement \\
\hline Offices & $\begin{array}{l}\text { 1055-1630 } \\
(\text { ANIA,2011) }\end{array}$ & 0.3 & $317-489$ & Based on expert judgement \\
\hline Transport & $\begin{array}{l}521 \quad(\min . \\
\text { resid.) }\end{array}$ & 0.29 & 150 & Based on expert judgement \\
\hline Agriculture & $\begin{array}{l}521 \quad(\min . \\
\text { resid.) }\end{array}$ & 0.19 & 100 & Based on expert judgement \\
\hline Recreational & $\begin{array}{l}1055-1630 \\
(\text { ANIA }, 2011)\end{array}$ & 0.3 & $317-489$ & Based on expert judgement \\
\hline $\begin{array}{l}\text { Temporary } \\
\text { lodging }\end{array}$ & $\begin{array}{l}521 \quad(\mathrm{~min} . \\
\text { resid.) }\end{array}$ & 0.10 & 52 & Based on expert judgement \\
\hline
\end{tabular}


transformed according to two proxy variables, employees density (ISTAT Istituto Nazionale di Statistica, 2012) and ratios between renting values (Agenzia delle Entrate, 2017).

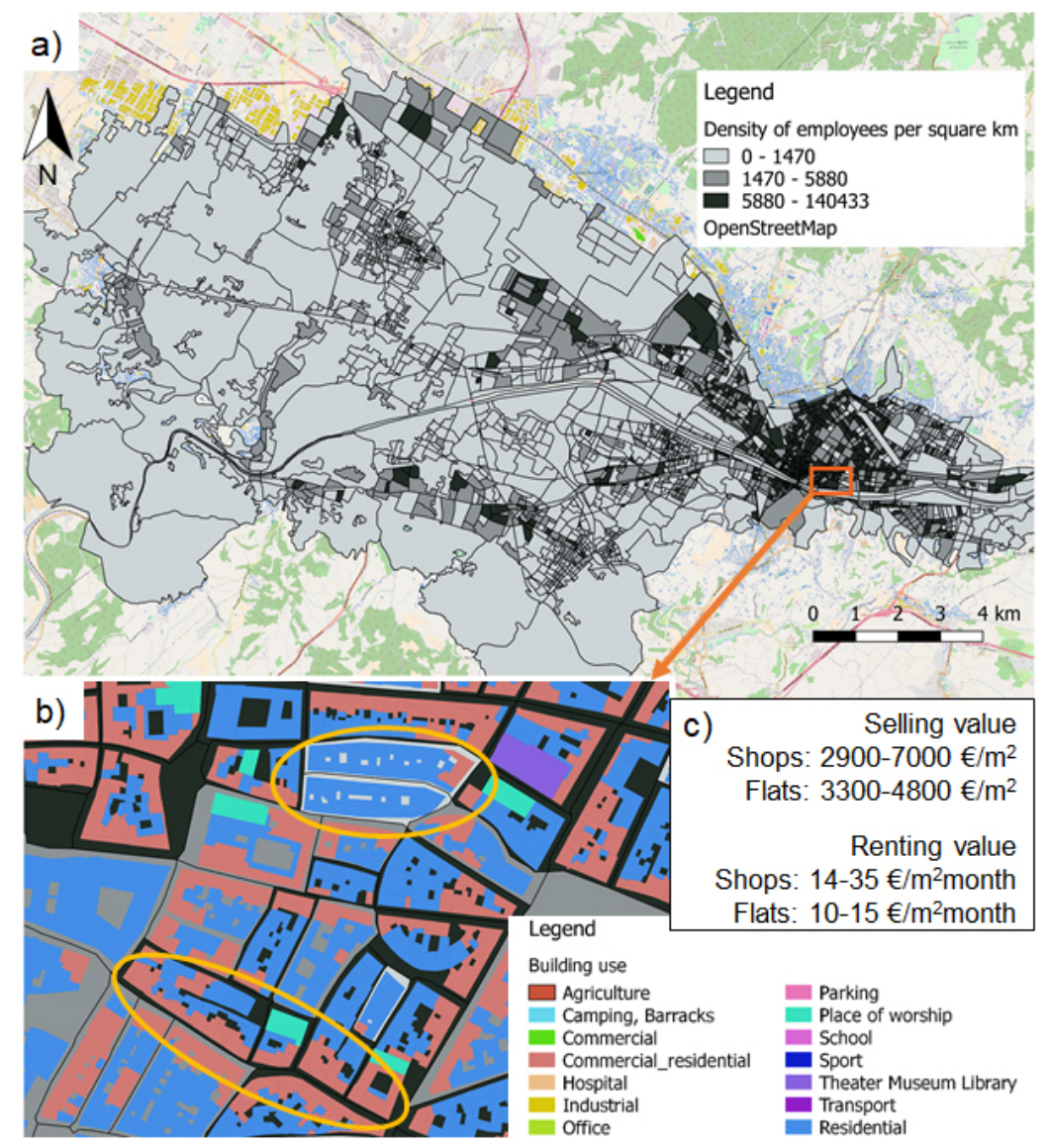

Figure 4: Density of employees per square km (ISTAT, 2012) (panel a), density of employees compared to building use (panel b) and examples of selling and renting values of the area of panel b (panel c). is considered a reliable socio-economic information which reflects the relevance of economic activities in the census polygons. In panel b of Figure 4 a detail of the historic district of Florence shows that a high density of employees (dark shades) adequately reflects the building use obtained by merging buildings data 
The average length of the business interruption is set equal to two months according to data collected in the last flood events in Tuscany (Albinia (GR), 2014 and Serchio river flood, 2012), where a general alignment has been observed among different economic sectors in the duration of business interruption 325 (Ufficio difesa del Suolo, Regione Toscana, personal communication). 


\subsection{Damage assessment}

Damage computation was carried out through the RASOR (Rapid Analysis and Spatialization Of Risk) platform (Rudari and RASOR TEAM, 2015 Koudogbo et al., 2014), which enables multi-hazard risk analysis for full-cycle disaster management. RASOR integrates diverse data and products across hazards. It allows one to easily update exposure data and to make scenario-based predictions to support both short- and long-term risk-related decisions (Silvestro et al. 2016). RASOR platform allows for the selection of suitable libraries of stage-damage curves, including the HAZUS-MH database (www.fema.gov/hazus) distributed by FEMA (Federal Emergency Management Agency Department of Homeland Security, 2010). The choice of the HAZUS-MH library as the primary set of flood vulnerability functions in the RASOR platform was due mainly to the possibility of assigning curves to a quite general set of building usage classes. This is not the first attempt to use curves defined for the USA context in the European one. For instance, (Jongman et al., 2012) insert the HAZUS functions for a review of flood depth-damage models at land use level in two European case studies, justifying their choice on the basis that they were developed in economically similar regions as the case studies. Moreover, this choice is supported by findings about the comparison of regional-level curves for North America and Europe in a recent JRC technical report (Huizinga et al., 2017); the authors show that the shapes of the functions for residential, commercial and industrial buildings in the two regions is quite similar, the functions for North America being based entirely on the HAZUS flood damage model. Nevertheless, the HAZUS occupancy classification doesnt take into account that European urban centres are rarely characterized by pure-commercial or pure-industrial buildings (this situation being almost non existing in the historical Italian urban centres), these two occupancy classes being usually mixed with the residential one. The original HAZUS-based taxonomy has been thus integrated, and generic mixedtype curves for two given occupancy classes have been developed by merging the corresponding damage curves for the single occupancy classes, the latter being used as bricks to be piled up (Fig. A supplementary material). This approach 
has been already described in Silvestro et al. (2016). The damage curves included in the RASOR libraries have been validated for the italian case study of Genoa. The 2014 Bisagno flood has been reproduced from the hydrologic and hydraulic point of view and damages have been estimated within the RASOR platform and validated using the citizen claims and post-event municipal surveys showing a good agreement between simulated and recorded flood losses (Trasforini et al. 2015). Although damage curves transferability is a debated issues, the urban characteristics of Genoa do not differ substantially from Florence ones and in absence of local data they are considered reliable. Moreover, in preliminary comparison between the previous study at census scale Arrighi et al. 2016a) and the current one, has shown a pretty good agreement. The methodology adopted by Arrighi et al. (2016a) had also a good performance in estimating the damages of the Veneto flood (northern Italy) when compared with observed losses (Scorzini and Frank, 2015).

\subsection{Risk and benefits of the mitigation measures}

Flood risk mitigation works like retention basins are usually designed to retain part of the flow discharge for reference flood scenarios. They have a minimum operational recurrence interval, i.e. they do not work below a certain flow discharge/water stage. This occurs for flood scenarios with expected acceptable losses. On the other hand, for catastrophic floods, i.e. far from the design scenarios, their benefit is extremely low or negligible. A robust risk mitigation strategy is capable of mitigating the adverse consequences of floods for a broad range of recurrence intervals. The benefit of the flood mitigation works for a reference scenario $B$ can be defined as

$$
B=1-\frac{D_{m}}{D_{0}}
$$

where $D_{0}$ is the damage in absence of any risk mitigation strategy and $D_{m}$ is the damage with mitigation works.

For high-frequency events, i.e. the mean annual flood, damages do not occur also without retention basins which do not activate, thus $B$ is virtually one. For 
than the design ones $D_{m}$ tends to $D_{0}$, thus $B$ is null. Between those extremes $B$ is comprised between 0 and 1 . The mathematical form of $B$ can be expressed as a function of the flood frequency (Olsen et al., 2015) $f$ with the advantage of having just one parameter to be calibrated,

$$
B=1-\exp (-a \cdot f)
$$

390

where $a$ is a parameter to be determined with estimated values of $D_{m}$ and $D_{0}$ derived by flood hazard and flood damage simulations.

For application purposes, where a limited number of flood damage scenarios in presence of mitigation works are estimated, eqs 1 and 2 allows for evaluating the damage-frequency curve in presence of mitigation strategies by using the following relationship

$$
D_{m}=D_{0} \cdot(1-(1-\exp (-a \cdot f)))
$$

which allows for visualizing the shifted EAD curve. Eq.3 can be used to obtain mathematically $D_{m}$ for those recurrence intervals where flood maps and damage assessments in presence of mitigation works are not available, having previously calibrated the parameter a (eq. 2) with the available (i.e. simulated) frequency$D_{0}$ and frequency- $D_{m}$ points.

Residual risk $R_{r}$ is the fraction of flood risk (as a percentage), which persists after the construction of hydraulic works. Usually, when mitigation strategies are conceived by public authorities, a certain level of flood safety is desired, e.g. zero damage for a given reference flood scenario with assigned probability. $R_{r}$ can be defined as a function of the amount $V$ (Mio euros) invested in flood risk mitigation. It can be expressed by an exponential law

$$
R_{r}=100 \cdot \exp (-c \cdot V)
$$

where 100 is the actual risk corresponding to zero investments and c is a parameter to be determined using flood risk assessment results. 
The intersection between $R_{r}$ curve and the desired residual risk $R_{r d}$ yields, cost is economically and environmentally sustainable nor that is cost-effective.

\section{Results and discussion}

Four flood scenarios in the current catchment configuration and two flood scenarios with active retention basins are considered. Official inundation maps have been provided by the Arno River catchment Authority. Flood depth maps have a spatial resolution of $1 \mathrm{~m}$ based on a LiDAR derived DTM of the same resolution.

Table 4 summarizes the damages estimated for the selected flood scenarios aggregating the losses to structures and contents of the different damage classes listed in Tables 2 and 3 . For an event of magnitude similar to the historical 1966 flood the estimated losses in the study area are about 15 billion euros only considering buildings, their contents and business interruption. Overall flood losses would further increase if population, infrastructures, vehicles and cultural heritage were considered.

Table 4: Total flood damages for the considered recurrence intervals and in presence of mitigation strategies

\begin{tabular}{lllll}
\hline Flood scenario & $\begin{array}{l}\text { Total damage } \\
(\text { Bln euro })\end{array}$ & $\begin{array}{l}\text { Total direct } \\
\text { damage } \\
\text { (Bln euro) }\end{array}$ & $\begin{array}{l}\text { Structures } \\
\text { (Bln euro) }\end{array}$ & $\begin{array}{l}\text { Contents } \\
\text { (Bln euro) }\end{array}$ \\
\hline 500-year & 14.81 & 12.71 & 6.01 & 6.70 \\
200-year & 9.57 & 8.05 & 3.75 & 4.30 \\
100-year & 4.47 & 3.78 & 1.82 & 1.96 \\
30-year & 0.57 & 0.49 & 0.27 & 0.22 \\
\hline 200-year (with reten- & 8.57 & 7.17 & 3.34 & 3.82 \\
tion basins) & & & & 0.12 \\
30-year (with reten- & 0.36 & 0.29 & & \\
tion basins) & & & & \\
\hline
\end{tabular}


The inundated areas for the four flood scenarios ordered by increased frequency are about $58 \mathrm{~km}^{2}, 56 \mathrm{~km}^{2}, 40 \mathrm{~km}^{2}$ and $10 \mathrm{~km}^{2}$ respectively. Corresponding average flood depths are $1.8 \mathrm{~m}, 0.95 \mathrm{~m}, 0.57 \mathrm{~m}$ and $0.55 \mathrm{~m}$. With the system of retention basins the inundated area decreases of about $2 \mathrm{~km}^{2}$ and $10 \mathrm{~km}^{2}$ for 200 and 30 years flood scenarios respectively and flood depth decreases up to 430 $1 \mathrm{~m}$ for both 200 years and 30 years scenarios (see supplementary material, Fig. $\mathrm{B}, \mathrm{C})$.

For the 200 years recurrence interval with active retention basins flood depths lowers of about $0.5 \mathrm{~m}$ in the historic district of the right bank. In the right bank suburban areas benefit of a $0.3 \mathrm{~m}$ reduction of the flood depth. In the left bank, 435 a flood depth reduction up to $1 \mathrm{~m}$ is achieved in the historic and semi-central districts. For the 30 years recurrence interval the suburban districts, which are the only affected, benefit of a flood depth reduction up to $1 \mathrm{~m}$. 


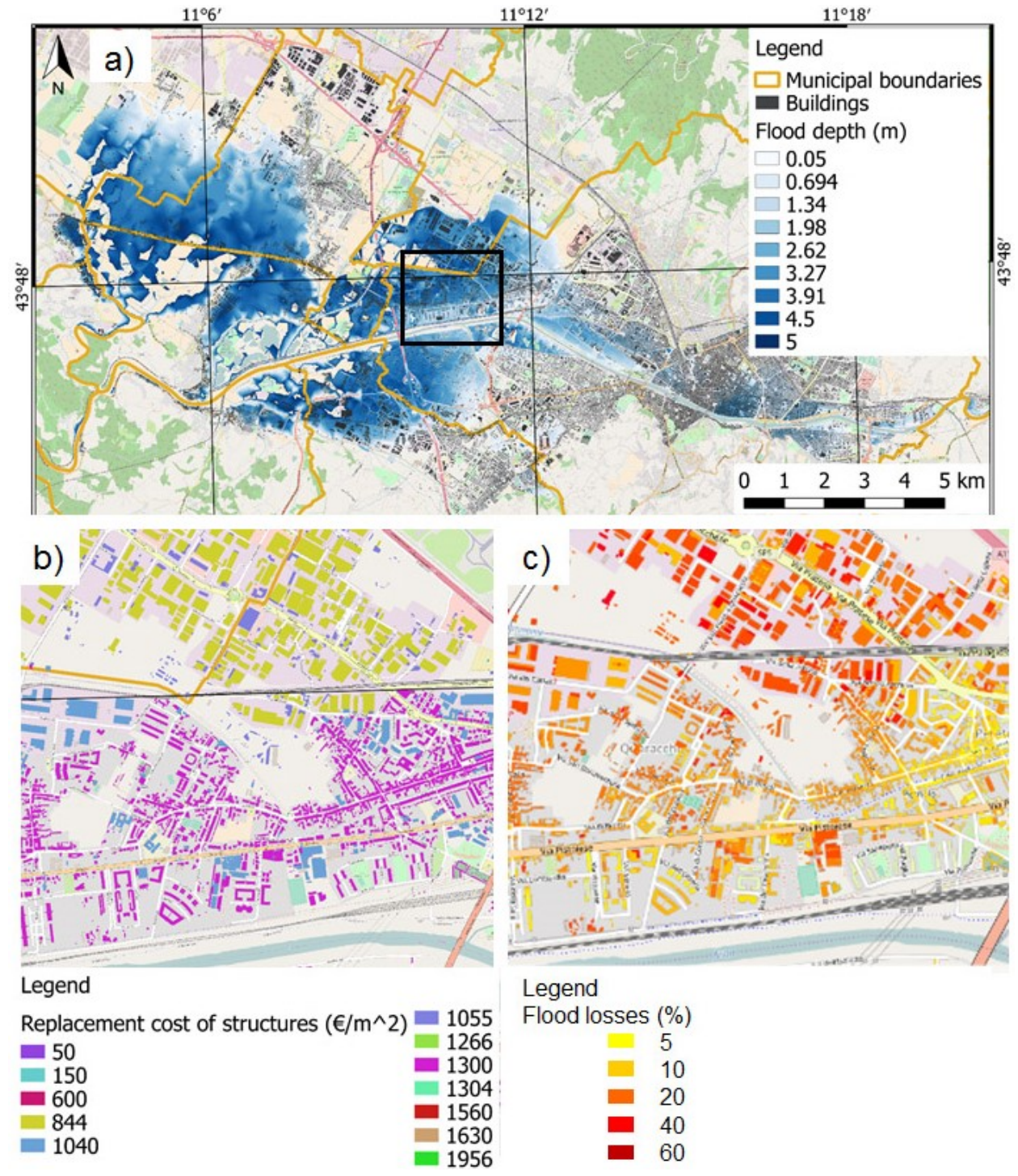

Figure 5: Flood map for the 500-year scenario (panel a), replacement cost for structures (panel b) and relative losses (panel c) in the sub-area indicated by the black rectangle in panel a

Figure 5 shows the flood depth map for the 500 years scenario (panel a) and the building-scale resolution of costs (panel b) and relative damage evaluated

through the RASOR platform (panel c). The inundated area is about $58 \mathrm{~km}^{2}$ 
and flood depths reach $6 \mathrm{~m}$ in the most depressed areas with an average value of $1.8 \mathrm{~m}$. Panel b of Fig 5 shows a detail of the replacement cost for structures in the subset area indicated by the black rectangle in panel a. Residential buildings in this suburban area are assigned the mean value of the range published by 445 Associazione Nazionale fra le Imprese Assicuratrici (2011) (Table 2). Panel c of Fig 5 shows a detail of the relative flood losses in the same area, which range from 5 to $45 \%$.

Figure 6 depicts the reduction of flood losses operated by the system of retention basins for the 200 years flood scenario. The top and bottom panels show a detail of the relative losses in absence and with risk mitigation works respectively for Signa, which is located downstream of Florence in the southwestern part of the inundated area shown in Fig 5 In the Signa area the relative damages decrease from $30 \%$ to $5 \%$ as shown by the color scale. The use of the building-scale to estimate relative and absolute flood losses allows for properly 455 accounting for the heterogeneity of the urban and suburban conurbation, often characterized by a gradual change in building use and market values moving from historic downtown to industrial areas. Figure 7 shows how the relative distribution of direct flood damages changes in different portions of the study area. 


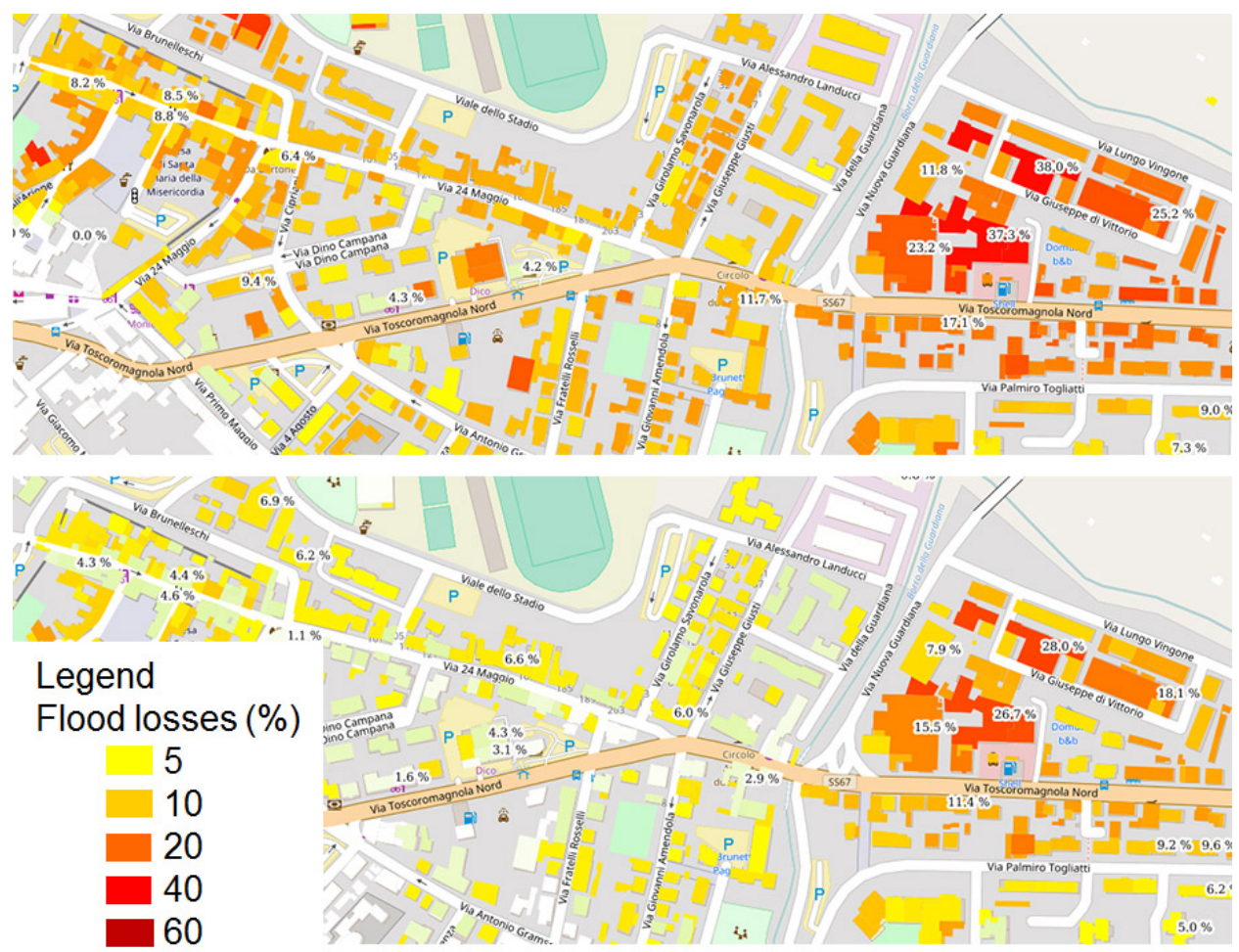

Figure 6: Flood losses in the actual scenario (top panel) and with the system of retention basins (bottom panel) for the 200 years reference scenario in Signa town (south west part of the inundated area in Fig 5 .

When the whole conurbation is considered (see Fig.5 panel a) damages to industrial structures cover almost half of the total (Fig. 7, panel a). When only the historic districts are considered (Fig. 7, panel b), losses to commercial activities are dominant over industrial ones and damages to residential buildings represent almost two third of the whole loss. 


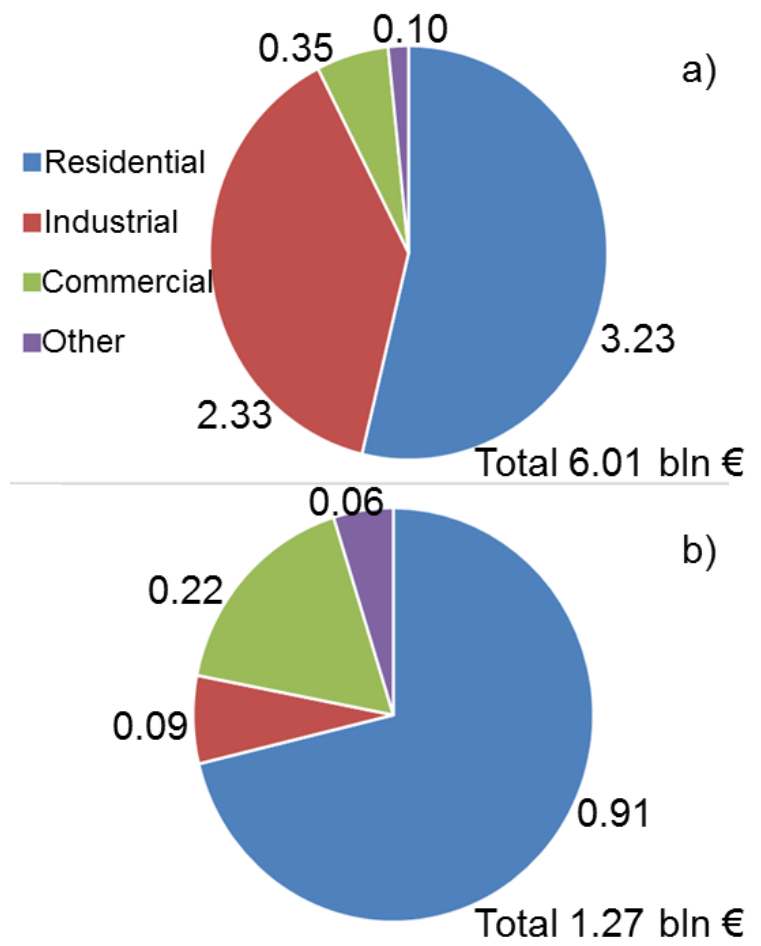

Figure 7: Monetary losses to structures for the 500 years flood scenario. Whole study area including urban area and suburbs (panel a), detail of the urban area (panel b)

The damage-frequency curve is drawn for the total losses (i.e. direct plus indirect due to business interruption) occurring in each base scenario and with the presence of the designed system of retention basins usign eq. 3 . Figure 8 depicts in black and red the risk curve for the actual scenario and the scenario with mitigation measures respectively. Apparently the risk reduction due to the system of retention basins is quite low. However, the calculation of flood risk in the two configurations demonstrates that the system of retention basins is costeffective with the adopted recovery costs and damage curves. Nevertheless, the availability of data to validate the damage model would be relevant to obtain more reliable results, given their high sensitivity with respect to adopted values.

Flood risk evaluated in the current condition is the integral of the black curve of Fig 8 and it is 169.6 Mio euros per year. With the new system of 


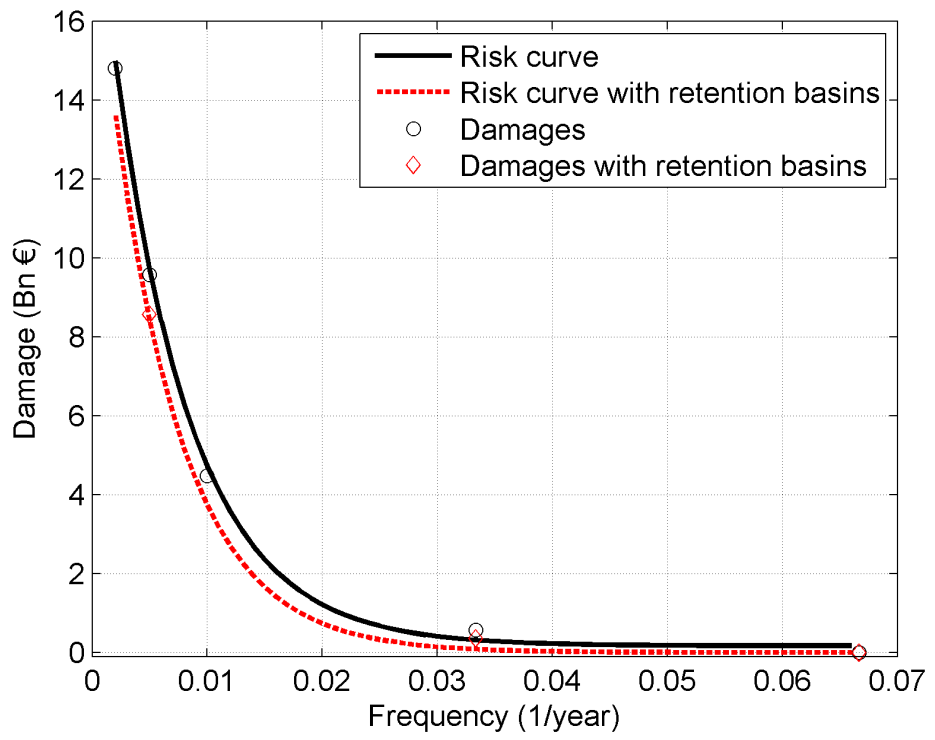

Figure 8: Risk curve in the actual condition and with operational retention basins (the red curve has been slightly shifted to ensure the readability of the plot)

retention basins the (integral of red curve in Fig 8 risk is 151.0 Mio euros per year, with an overall reduction of 18.6 Mio euros per year. This value represents the benefit of the flood risk mitigation measures. Since the estimated cost of the work is 74.14 million euros in approximately four years the initial investment is paid off. Moreover, the annual maintenance costs including hydraulic work supervision and ordinary maintenance of electro-mechanic devices, levees and basins are estimated as being about $2 \%$ of the construction cost, i.e. 1.5 Mio euros per year. Thus, they are sustainable with respect to the benefits of the system of retention basins.

In the study area, the authorities would like to obtain zero damages for the 200 years flood scenario through risk mitigation strategies. With reference to Fig 8 , this means to shift and stretch to the left side of the diagram the red risk curve in order to set the damage for 0.005 frequency to zero. The desired residual risk $R_{r d}$ is the integral of the new curve and its value, obtained graphically, is about $18 \%$ of the current flood risk. 


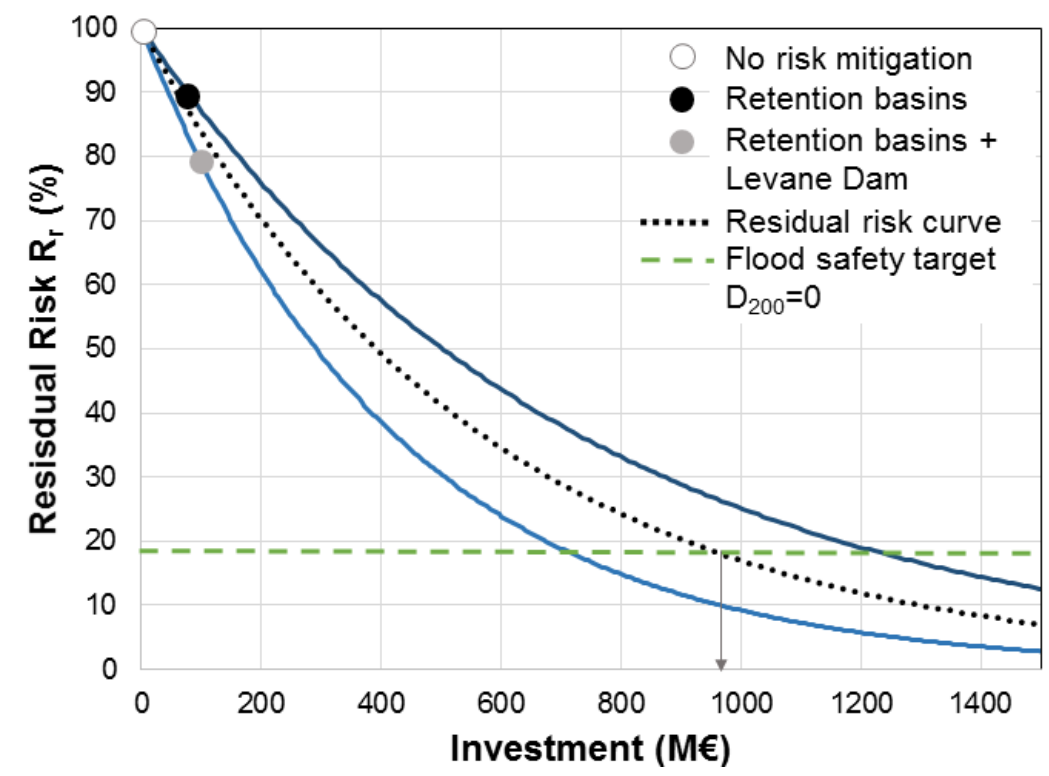

Figure 9: Residual risk curves to obtain the theoretical investment to satisfy the flood safety target (green dashed line)

$R_{r d}$ equal to $18 \%$ is depicted in Fig 9 with green dashed line. The upper blue curve represents the regressed exponential curve obtained by eq. 4 using the risk reduction obtained by flood risk estimation carried out accounting for the system of retention basins in Table 1. In this scenario $R_{r}$ is $89 \%$ (black dot). The lower blue curve represents the regressed exponential curve obtained by eq. 4 using the predicted risk reduction achieved by combining the system of retention basins with the increase of storage capacity of Levane dam (grey dot). According to a preliminary hydraulic assessment of the project designers the adjustment of Levane dam crest is expected to have a synergic action with the retention basins, whose benefit is much larger than the sum of the single effects (Regione Toscana, personal communication) with an expected residual risk of $76 \%$.

If both the quantitative risk assessment carried out in this work and the official prediction are used for the regression of the $R_{r}$ curve (i.e. all the three points are used for calibrating c), the black dotted curve of Fig 9 is obtained. If 
several risk mitigation scenarios are accounted for and simulated, the shape of the dotted curve better intercepts the theoretical investment required to reach $R_{r}=18 \%$. The intersection with the flood safety target $R_{r d}$ yields a theoretical

\subsection{Strengths and Limitations}

The work presented in this manuscript has its major strengths in (i) the effort in the characterization of a building scale exposure by merging several sources of open-data, (ii) the capability of handling such a detail in a large case study area by using the RASOR platform, (iii) the presentation of an analytical approach to estimate the investment required for achieved a desired level of residual risk. The research has also some limitations which could be overcome by a future development. Main limitations are first, the use of a parsimonious flood model, which does not account for the cascading effects of possible wood the damage model is not validated with local data but with a similar urban area in Northern Italy and experts' opinion has been used to overcome the lack of reliable data. Being the recovery/replacement values multiplicative, an error in their estimation propagates in the final damage estimate, with an elasticity equal average values to local ones is considered as a good compromise to estimate recovery costs in national applications, being aware of the high sensitivity of the final result to these values.

\section{Conclusions}

This work has described a single building-scale characterization and risk assessment, which is unusual for the large spatial extent of the study area. This was made possible on one hand, thanks to the availability of several sources of open data (buildings polygons and their main use, punctual information on commercial activities) and thanks to the capabilities of the RASOR platform al- 
on the other. The methodology is easily transferable and adaptable to any urban context where similar urbanization and geographic datasets of exposure (e.g. building polygons) are available. Florence (Italy) is an exemplary case study for the relevance of exposed assets and open data availability. The single building-scale will also allow for tracking the building use changes and recovery cost values in the study area, based on market values updates.

For an event of magnitude similar to the historical 1966 flood the estimated losses in the study area are about 15 billion euros without considering population, infrastructures, vehicles and cultural heritage which would further aggravate the overall impact of the flood event. The cost-effectiveness of the designed system of retention basins upstream of the city of Florence, is considered as demonstrated, although the damage model has not been validated with local data. Nevertheless, a flood risk reduction of 18.6 Mio euros per year, although relevant in monetary terms, is not enough to protect such a large area, especially the suburban areas, which after the devastating 1966 flood has been transformed into a dense productive area ignoring its high flood hazard. Moreover, the flood depth reduction achieved by the retention basins in the historic districts (of the order of $0.5 \mathrm{~m}$ ) has a marginal effect, thus the management of residual flood risk is fundamental. This may include specific retrofitting mea555 sures for buildings and cultural heritage, warning systems and civil protection mechanisms.

The system of retention basins however, is only the first step towards the flood risk mitigation in the Florence area, which remains one of the national priorities. The increase of the storage capacity of the Levane dam (5-7 $\mathrm{m}$ of increase of the crest) will also strongly contribute to a further risk reduction and the method adopted in this study could be replicated to evaluate its benefits. The method also allowed for answering a common stakeholders' question, i.e estimating the theoretical investment (about 1 Bln euros) to obtain the desired level of flood safety, i.e. zero damage for 200 years flood scenario. The value appears quite ambitious and does not ensure nor economic or environmental sustainability. However, it demonstrates the need of a more detailed assessment 
of quantitative risk reduction under further hazard mitigation scenarios and the adequacy of the risk assessment methodology to support stakeholders' decisions.

\section{Software and data availability}

The RASOR platform (Rapid Analysis and Spatialisation of Risk) is open access via free registration on the website http://www.rasor-project.eu/. Open data used in the work are available in the following data portals:

- http://www502.regione.toscana.it/geoscopio

- www.adbarno.it/opendata

575

- opendata.comune.fi.it 


\section{References}

Agenzia delle Entrate, 2017. Servizio di navigazione territoriale quotazioni im-

口 mobiliari. Technical Report. URL: wwwt.agenziaentrate.gov.it/geopoi_ omi.

${ }_{580}$ Alfieri, L., Feyen, L., Salamon, P., Thielen, J., Bianchi, A., Dottori, F., Burek, P., 2016. Modelling the socio-economic impact of river floods in Europe.

口 Natural Hazards and Earth System Sciences 16, 1401-1411. doi 10.5194/ nhess-16-1401-2016.

Apel, H., Aronica, G.T., Kreibich, H., Thieken, A.H., 2009. Flood risk analyses

585 \ - How detailed do we need to be? Natural Hazards 49, 79-98. doi 10.1007/ s11069-008-9277-8.

Arrighi, C., Brugioni, M., Castelli, F., Franceschini, S., Mazzanti, B., 2013. Urban micro-scale flood risk estimation with parsimonious hydraulic modelling and census data. Natural Hazards and Earth System Sciences 13, 1375-1391. doi:10.5194/nhess-13-1375-2013.

Arrighi, C., Brugioni, M., Castelli, F., Franceschini, S., Mazzanti, B., 2016a. Flood risk assessment in art cities: The exemplary case of Florence (Italy). Journal of Flood Risk Management, 1-16doi $10.1111 /$ jfr3.12226.

Arrighi, C., Huybrechts, N., Ouahsine, A., Chassé, P., Oumeraci, H., Castelli, F., 2016b. Vehicles instability criteria for flood risk assessment of a street network. Proceedings of the International Association of Hydrological Sciences 373, 143-146. URL: https://www.proc-iahs.net/373/143/2016/, doi:10.5194/piahs-373-143-2016.

Arrighi, C., Tarani, F., Vicario, E., Castelli, F., 2017. Flood impacts on a water distribution network. Natural Hazards and Earth System Sciences Discussions

n 2017, 1-22. URL: https://www.nat-hazards-earth-syst-sci-discuss. net/nhess-2017-205/, doi 10.5194/nhess-2017-205. 
Associazione Nazionale fra le Imprese Assicuratrici, 2011. Danni da eventi sismici e alluvionali al patrimonio abitativo italiano: studio quantitativo e possibili schemi assicurativi. Technical Report. URL:

Autorità di Bacino del Fiume Arno, 2016a. Piano di Gestione del RIschio n Alluvioni (PGRA) Parte 1. Technical Report. URL: http://www.adbarno. it/adb/?page\{_\}id=4826.

Autorità di Bacino del Fiume Arno, 2016b. Piano di Gestione del RIschio

\ Alluvioni (PGRA) Parte 2. Technical Report. URL: http://www.adbarno. it/adb/?page\{_\}id=4826.

Aye, Z.C., Jaboyedoff, M., Derron, M.H., Van Westen, C.J., Hussin, H.Y., Ciurean, R.L., Frigerio, S., Pasuto, A., 2016. An interactive web-GIS tool for risk analysis: A case study in the Fella River basin, Italy. Natural Hazards and Earth System Sciences 16, 85-101. doi:10.5194/nhess-16-85-2016.

Ballio, F., Molinari, D., Minucci, G., Mazuran, M., Arias Munoz, C., Menoni, S., Atun, F., Ardagna, D., Berni, N., Pandolfo, C., 2015. The risposta procedure for the collection, storage and analysis of high quality, consistent and reliable damage data in the aftermath of floods. Journal of Flood Risk Management , n/a-n/aURL: http://dx.doi.org/10.1111/jfr3.12216, doi 10 . $1111 / j f r 3.12216$

Burzel, A., Dassanayake, D., Oumeraci, H., 2015. Spatial modeling of tangible and intangible losses in integrated coastal flood risk analysis. Coastal Engineering Journal 57, 255-270. doi doi:10.1142/S0578563415400082.

Campo, L., Caparrini, F., Castelli, F., 2006. Use of multi-platform, multi temporal, remote sensing data for calibration of a distributed hydrological model: and application in the arno basin, italy. Hydrological Processes 20, 2693-2712. doi:10.1002/hyp.6061. 
Caporali, E., Rinaldi, M., Casagli, N., 2005. The arno river floods. Gior-

q nale di Geologia Applicata 1, 177-192. URL: http://dx.doi.org/10.1029/ E0060i001p00001-01, doi doi:10.1474/GGA.2005-01.0-18.0018

Dottori, F., Figueiredo, R., Martina, M., Molinari, D., Scorzini, A.R., 2016. INSYDE: a synthetic, probabilistic flood damage model based on explicit cost analysis. Natural Hazards and Earth System Sciences Discussions , 1-23URL: http://www.nat-hazards-earth-syst-sci-discuss. net/nhess-2016-163/, doi 10.5194/nhess-2016-163.

EU Parliament, 2007. Directive 2007/60/EC.

${ }_{640}$ Federal Emergency Management Agency Department of Homeland Security, 2010. BCA Reference Guide. Technical Rea port. URL: https://www.fema.gov/media-library-data/

4. 1396550224865-548160e5f22dabb793d8a045fa89f5fe/bca_reference _ guide_508_final.pdf.

${ }_{645}$ Förster, S., Kneis, D., Gocht, M., Bronstert, A., 2005. Flood risk reduction by the use of retention areas at the Elbe River. International Journal of River Basin Management 3, 21-29. doi 10.1080/15715124.2005.9635242.

Gouldby, B.P., Sayers, P.B., Tarrant, O., 2008. Application of a flood risk model to the Thames Estuary for economic benefit assessment. WIT Transactions

on Information and Communication Technologies 39, 11-19. doi 10.2495/ RISK080021.

Huizinga, J.and de Moel, H., Szewczyk, W., 2017. Global flood depth-damage functions. Methodology and the database with guidelines. Technical Report. URL: http://publications.jrc.ec.europa.eu/repository/bitstream/ JRC105688/global_flood_depth-damage_functions__10042017.pdf. eUR 28552.

ISTAT Istituto Nazionale di Statistica, 2012. Censimento dell'industria e dei servizi 2011. Technical Report. URL: http://www.istat.it 
Jongman, B., Kreibich, H., Apel, H., Barredo, J.I., Bates, P.D., Feyen, L., Gericke, A., Neal, J., Aerts, J.C.J.H., Ward, P.J., $2012 . \quad$ Comparative flood damage model assessment: towards a european approach. Natural Hazards and Earth System Sciences 12, 3733-3752. URL:

${ }_{665}$ Koudogbo, F., Duro, J., Rossi, L., Eddy, A., 2014. Multi-hazard risk analysis using the fp7 rasor platform. Proceedings of SPIE Remote Sensing for \ Agriculture, Ecosystems, and Hydrology 92390J, 2538. doi DOI:10.1117/12. 2067444 ,

Marin, G., Modica, M., 2017. Socio-economic exposure to natural disas670 ters. Environmental Impact Assessment Review 64, 57-66. URL: http:

a //linkinghub.elsevier.com/retrieve/pii/S0195925516303286, doi 10. 1016/j.eiar.2017.03.002.

Meyer, V., Becker, N., Markantonis, V., Schwarze, R., Van Den Bergh, J.C.J.M., Bouwer, L.M., Bubeck, P., Ciavola, P., Genovese, E., Green, C., Hallegatte, ${ }_{675}$ S., Kreibich, H., Lequeux, Q., Logar, I., Papyrakis, E., Pfurtscheller, C., Poussin, J., Przyluski, V., Thieken, a.H., Viavattene, C., 2013. Review article: Assessing the costs of natural hazards-state of the art and knowledge gaps.

ه Natural Hazards and Earth System Science 13, 1351-1373. doi 10.5194/ nhess-13-1351-2013.

de Moel, H., van Vliet, M., Aerts, J.C.J.H., 2014. Evaluating the effect of flood damage-reducing measures: a case study of the unembanked area of rotterdam, the netherlands. Regional Environmental Change 14, 7 895-908. URL: http://dx.doi.org/10.1007/s10113-013-0420-z, doi 10 . 1007/s10113-013-0420-z.

${ }_{685}$ Molinari, D., Ballio, F., Menoni, S., 2013. Modelling the benefits of flood emergency management measures in reducing damages: a case study on sondrio, italy. Natural Hazards and Earth System Sciences 13, 1913-1927. URL: 
https://www.nat-hazards-earth-syst-sci.net/13/1913/2013/, doi:10. 5194/nhess-13-1913-2013.

690 Murnane, R., Simpson, A., Jongman, B., $2016 . \quad$ Understanding risk: what makes a risk assessment successful? International Journal of Disaster Resilience in the Built Environment 7, 186-200. URL: https://www.scopus.com/inward/record.uri?

1) eid=2-s2.0-85010682372\&doi=10.1108\%2f I JDRBE-06-2015-0033\&

partnerID=40\&md5=50cd50fd4f6669d3e5108a2609586c60, doi $10.1108 /$ IJDRBE-06-2015-0033. cited By 0.

Olsen, A., Zhou, Q., Linde, J., Arnbjerg-Nielsen, K., 2015. Comparing methods of calculating expected annual damage in urban pluvial flood risk assessments. Water 7, 255-270. doi:10.3390/w7010255.

Panattoni, L., Wallis, J.R., 1979. The arno river flood study (19711976). Eos, \ Transactions American Geophysical Union 60, 1-5. URL: http://dx.doi. org/10.1029/E0060i001p00001-01, doi:10.1029/E0060i001p00001-01.

Penning-Rowsell, E.C., Pardoe, J., 2012. Who benefits and who loses from flood risk reduction? Environment and Planning C: Government and Policy 30, 448-466. doi:10.1068/c10208.

Prahl, B.F., Rybski, D., Boettle, M., Kropp, J.P., 2016. Damage functions for climate-related hazards: Unification and uncertainty analysis. Nat-

n ural Hazards and Earth System Sciences 16, 1189-1203. doi 10.5194/ nhess-16-1189-2016.

Regione Toscana, 2016. Prezzario Regionale Lavori Pubblici. Technical Report. URL: http://prezzariollpp.regione.toscana.it/\#2016/2.

Rojas, R., Feyen, L., Watkiss, P., 2013. Climate change and river floods in the European Union: Socio-economic consequences and the costs and benefits of adaptation. Global Environmental Change 23, 1737-1751. URL: 
http://dx.doi.org/10.1016/j.gloenvcha.2013.08.006 doi:10.1016/j. gloenvcha.2013.08.006

Rudari, R., RASOR TEAM, 2015. Rasor project: Rapid analysis and spatialization of risk, from hazard to risk, using eo data. Geophys. Research

10 Abstracts 17, 2538. URL: https://www.researchgate.net/publication/ 720 303018479_RASOR_Project_Rapid_Analysis_and_Spatialisation_of_ Risk_from_Hazard_to_Risk_using_EO_data.

Ruiz-Villanueva, V., Wyga, B., Miku, P., Hajdukiewicz, M., Stoffel, M., 2017. Large wood clogging during floods in a gravel-bed river: the dugopole bridge in the czarny dunajec river, poland. Earth Surface Processes and Landforms 42, 516-530. URL: http://dx.doi.org/10.1002/esp.4091, doi10.1002/ esp.4091. eSP-16-0137.R2.

Scawthorn, C., Flores, P., Blais, N., Seligson, H., Tate, E., Chang, S., Mifflin, E., Thomas, W., Murphy, J., Jones, C., Lawrence, M., 2006. HAZUSMH Flood Loss Estimation Methodology. I: Overview and Flood Hazard

730 - Characterization. Natural Hazards Review 7, 72-81. doi 10.1061/(ASCE) $1527-6988(2006) 7: 2(72)$

Scorzini, A., Frank, E., 2015. Flood damage curves: new insights from the 2010 flood in veneto, italy. Journal of Flood Risk Management 10, 381-392. URL: http://dx.doi.org/10.1111/jfr3.12163, doi:10.1111/jfr3.12163

Shreve, C.M., Kelman, I., 2014. Does mitigation save? Reviewing cost-benefit analyses of disaster risk reduction. International Journal of Disaster Risk Reduction 10, 213-235. URL: http://dx.doi.org/10.1016/j.ijdrr.2014. 08.004 , doi $10.1016 / j . i j d r r .2014 .08 .004$.

Silvestro, F., Rebora, N., Rossi, L., Dolia, D., Gabellani, S., Pignone, F., 740 Trasforini, E., Rudari, R., De Angeli, S., Masciulli, C., 2016. What if the 25 October 2011 event that struck Cinque Terre (Liguria) had happened in Genoa, Italy? Flooding scenarios, hazard mapping and damage 
estimation. Natural Hazards and Earth System Sciences 16, 1737-1753. doi:10.5194/nhess-16-1737-2016.

Sterlacchini, S., Zazzeri, M., Cappellini, G., Pastormerlo, M., Bonazzi, A., 2016.

An open source gis-based tool for economic loss estimation due to flood events. PeerJ Preprints doi/https://doi.org/10.7287/peerj.preprints.2228v1.

Trasforini, E.and De Angeli, S., Fiorini, M., Rossi, L., Rudari, R., 2015. Use of crowd source, open data and eo-based information in flood damage assessment: the 2014 urban flood in genoa. Geophys. Res. Abstr. EGU General assembly 17 .

USACE, 2006. Depth-Damage relationships for structures, contents and vehicles and content-to-structure value ratios (CSVR) in support of the Donaldsonville

q to the gulf, Louisiana, feasibility study. Technical Report. URL: http://www. mvn.usace.army.mil/Portals/56/docs/PD/Donaldsv-Gulf .pdf.

Van Ootegem, L., Verhofstadt, E., Van Herck, K., Creten, T., 2015. Multivariate pluvial flood damage models. Environmental Impact Assessment Review

a 54, 91-100. URL: http://www.sciencedirect.com/science/article/pii/ S0195925515000505, doi $10.1016 /$ j.eiar.2015.05.005. 